\title{
Preferred Learning Styles of Accounting Students in Senior Secondary Schools in Imo State, Nigeria
}

\author{
Dr. Nkeiruka P. Francis ${ }^{1 *} \quad$ Dr. Joy N. Oruwari ${ }^{1,2}$ \\ 1.Department of Social Science Education, Faculty of Education, Imo State University, Owerri, Nigeria \\ 2.Department of Curriculum/Instruction, Alvan Ikoku Federal College of Education, Owerri, Imo State, Nigeria
}

\begin{abstract}
This study investigated the Preferred Learning Styles of Accounting Students in Senior Secondary Schools in Imo State, Nigeria. The quasi-experimental research design was adopted for the study. Two instruments were used for the study - (a) The Kolb learning styles inventory (1999 version) (LSI) was used to identify the students learning styles (b) The Accounting Achievement Test (AAT) for pretest and posttest. The sample comprised 300 senior secondary school (SSS) students selected from three secondary schools drawn from the state. The schools covered by the study comprised three categories: (1) one boys' school, (2) one girls' school and (3) one co-educational. A purposive sampling technique was used to select one school from each category while a simple random sampling technique was used to select the student-sample of 100 students from each school making it a total of 300 students. The reliability of the instruments (LSI and AAT) were ascertained by the use of Cronbach alpha statistic and Kuder Richardson formula $20(\mathrm{~K}-\mathrm{R}) 20$ respectively. Two research questions and one hypotheses guided the study. The research questions were answered with percentages, means and standard deviation while the hypotheses were tested with ANCOVA at 0.05 level of significance. The findings shows that the Learning Style Preference of Accounting Students is Converging. Results revealed that when teaching method match the students learning styles they perform better. Based on the findings, the researcher recommends among others that: for better performances in accounting, Accounting teachers should identity the learning styles of their students and use teaching strategies that complements them; varieties in the teaching and learning process like grouping and teaching of students on the basis of their learning style preferences when possible; the Government and the Ministries of Education should recruit only qualified accounting teachers, adequate relevant instructional materials and facilities should be provided for schools; Curriculum Planners and Experts should plan and organize the curriculum bearing in mind individual differences in learning styles of students, etc.
\end{abstract}

Keywords: Preference, Learning Styles, Accounting

DOI: $10.7176 / \mathrm{JEP} / 12-35-02$

Publication date: December $31^{\text {st }} 2021$

\section{Introduction}

Throughout history, the major responsibility of schools has been to prepare students for the future. As educators have pursued this goal, they have developed different philosophies regarding how students learn (Draper, 2004). Dewey (1938) as cited by Kolb (1999) opined that education prepares students to handle future responsibilities and be successful in life by acquiring knowledge and skills through instructional content.

Modern education is facing a lot of problems. It is the attempt to tackle these problems that led to the application of new or innovative teaching-learning systems which is the use of multiple teaching methods in teaching. Such new teaching-learning systems focus attention on the use of organized and combined set of people, materials, equipment, facilities and methodologies to accomplish the desired instructional specific objectives. All students learn, but not all learn in the same way. The inability of teachers to identify the most appropriate teaching style may affect students (Salcedo,2021). Some grasp information best by listening, while others learn better through reading, reasoning, or discovering concepts through a hands-on experience. In some cases, it may be difficult to tailor coursework to the individual learning styles of each student. However, in these situations, by being aware of their learning styles, the students may contribute to their academic success by promoting selfawareness and their use of learning strategies that work for their learning style (Tanner and Allen, 2004). It is essential that an instructor's teaching style provide access for students with different learning styles during the experiences of a course. A good match between students' learning preferences and instructor's teaching style has been demonstrated to have positive effect on student's performance (Harb and El-Shaarawi, 2006). Mbakwem and Mkpa (2003) observed that when teaching style is matched with the learner's cognitive operation (learning style), teaching and learning become more productive and rewarding. A good match between students' learning preferences and instructor's teaching style has been demonstrated to have positive effect on student's performance (Harb and El-Shaarawi, 2006). Kolb (1984:41), defines learning as "the process whereby knowledge is created through the transformation of experience. Knowledge results from the combination of grasping and transforming experience".

Learning style as seen by (Kolb, 2000, p. 1) is "the way we prefer to absorb and incorporate new information". To Kolb, learning style has to do with the manner in which the students or the learners take in and understand any 
new lesson that is presented them. The absorption of new lesson appeals to different people in different ways and none of the ways they learn is right or wrong. Kolb (1999) has developed four learning styles with which to identify the learners' learning styles. These are accommodating, diverging, assimilating and converging learning styles, these according to him are the four different ways learners can perceive knowledge.

Given various preferences for perceiving and processing information, Kolb (1984) has suggested four different learning styles: Accommodator, Diverger, Assimilator, and Converger (see Figure 1).

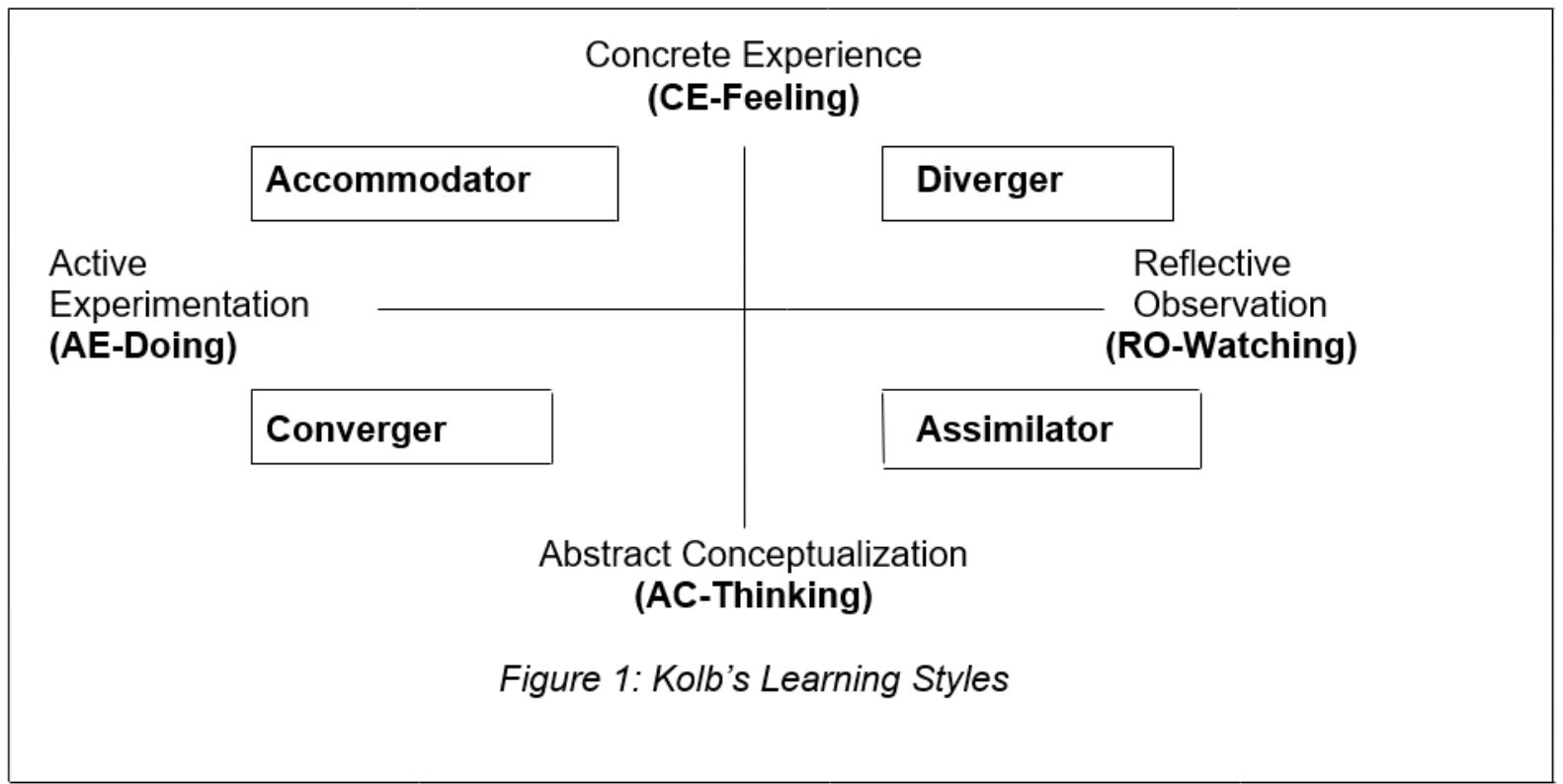

The Experiential Learning Model (ELM) devised by Kolb (1984) and its associated learning style takes an information processing approach to learning which has been applied in medicine, engineering, management, marketing and accounting. Essentially the ELM is a four stage cyclical process, where students who learn effectively will experience all four stages at different times in the learning process and can move backward and forward through the stages, depending on what is being taught and the method used. The learner will generally have a preference for one particular style and, as their learning develops, that preference may change to a different style (McCarthy, 2010).

The model has two opposing directions of how the experience and information is perceived - concrete experience $(\mathrm{CE})$ and abstract conceptualization (AC), and two opposing directions of processing the experience and information - reflective observation (RO) and active experimentation (AE). Four types of learning styles emerge from this model - divergers, assimilators, convergers and accommodators (Kolb 1984).

Divergers perceive learning through CE and process the learning through RO. They view situations from many different perspectives, are imaginative, interested in people and usually specialize in the arts (Baldwin and Reckers, 1984; Kolb 1984; McCarthy 2010). Assimilators perceive learning through AC and process it through RO. They create theoretical models from inductive reasoning, but are not concerned about practical application of the model or about people. Assimilators would normally be found in the sciences (McCarthy, 2010). Assimilators are also called theorists and can be simply described with the words think \& watch (Honey \& Peter, 2006). Convergers perceive learning through AC and process it through AE. Their greatest strength is in the practical application of ideas to solve problems and make decisions. They use hypothetical deductive reasoning to focus on specific problems and perform best in situations where there is one correct answer. Accountants and engineers generally adopt a convergent learning style (Kolb, 1984; McCarthy, 2010). Lastly, accommodators perceive learning through $\mathrm{CE}$ and process it through AE. Their strength is in doing things, carrying out plans and taking risks to excel in new situations. Accommodators are often found in active, practical jobs such as business, marketing and sales (Baldwin and Reckers, 1984; Kolb, 1984; McCarthy, 2010).

A number of studies have examined the learning styles of accounting students using the LSI. These have shown that accounting students overall have different learning styles from other business students and generally prefer a convergent learning style (Baker et al., 1986; Brown and Burke, 1987). The reason behind these finding is because Accounting is better learnt, understood and mastered by actually working exercises. Exercise given are adequately evaluated, marked and appropriate feedback given to the students. These objectives are geared towards making the students to appreciate the rules and functions of accounting, lay a sound foundation for further study of accounting at higher level and also assess candidates' knowledge of basic accounting principles and their application to modern business activities. 


\section{Statement of the Problem}

The problem of poor performance of students in external examinations especially in accounting have continued to be a source worry to the teachers, parents, the learners themselves even the Nigerian education sector in general. One begins to wonder if other factors could be responsible for the large number of failures in Financial Accounting other than the ones already identified. Could knowledge and utilization of learners' learning styles in selecting appropriate teaching methods help to improve performance? Would matching teaching strategies with students learning styles, make their performance to be enhanced? This is the problem of this study.

\section{Objectives}

The study was specifically designed to examine the following:

* $\quad$ find out the learning preferences of accounting students

* ascertain the effect of Converging and Assimilating learning styles on the students' performances.

\section{Research Questions}

The following research questions were posed for the study:

1. What are the learning styles that exist amongst SS 2 Financial Accounting Students?

2. What differences exist in adjusted Accounting mean scores of students in Converging and assimilating learning styles and Control groups at posttest?

\section{Hypotheses}

Hol: There is no significant difference in the adjusted Accounting mean scores of students in the Assimilating and Converging learning styles groups and Control group at posttest

\section{METHODOLOGY}

\section{Research Design}

This research adopts a quasi-experimental research design. This type of research design was used because the researcher did not have full control over some of the intervening variables, that is, those things capable of impinging on the results such as classroom arrangements, health, studying together and or comparing notes, resources available to students beyond treatment session and or after school, etc.

\section{Population of Study}

This research work was carried out in Owerri Municipal Council of Imo State of Nigeria. All Senior Secondary School Class II (SS II) Financial Accounting students in all the eight (8) Public Senior Secondary Schools in Owerri Municipal Council totaling 3368 made up the population of the study.

Table 1: The eight (8) Public Senior Secondary Schools in Owerri Municipal Council of Imo State:

\begin{tabular}{|c|c|c|c|c|}
\hline $\mathbf{S} / \mathbf{N}$ & Name of School & No. of SS 2 Students & Males & Females \\
\hline 1 & Boys' Secondary School New Owerri & 300 & 300 & \\
\hline 2 & Comprehensive Dev. Sec. Sch. Douglas Rd. Owerri & 649 & 291 & 358 \\
\hline 3 & Emmanuel College Owerri & 250 & 250 & \\
\hline 4 & Government Secondary School Owerri & 750 & 750 & \\
\hline 5 & Government Technical College Owerri & 479 & 479 & \\
\hline 6 & Ikenegbu Girls' Secondary School Owerri & 627 & & 627 \\
\hline 7 & Urban Development Secondary School New Owerri & 313 & 89 & 224 \\
\hline 8 & Young Scientists College Owerri & 179 & 97 & 82 \\
\hline & Total & 3368 & 2159 & 1209 \\
\hline
\end{tabular}

\section{Sample and Sampling Techniques}

The eight senior secondary schools were first arranged into three clusters according to school types. The three clusters are (a) Co-educational or mixed schools, (b) All boys' schools and (c) All girls' schools. A purposive sampling technique was used to pick one school from each cluster. The sample that was used in this study was 300 SS II Accounting students comprising of (150 males and 150 females) obtained through simple random sampling from the three sampled secondary schools in Owerri Municipal Council, 100 students from each sampled school.

\section{Instrumentation}

In collecting data for this study, two instruments were used: Kolb Learning Style Inventory (LSI) 1999 version and Accounting Achievement Test (AAT). Kolb Learning Style Inventory (LSI 1999 version) was used for the identification of the students' learning styles. The instrument contains 12 questions; this required the respondents 
to rank statements that reflect the four modes for perceiving and processing information, which helped to identify the individual's preferences for each of the modes. These modes of perceiving and processing information are the four learning styles adopted from Kolb (1999), these are Accommodating, Diverging, Converging and Assimilating. The Accounting Achievement Test (AAT) was used for the determination of the students' performance in both the pretests and post-tests. The AAT that is based on the SS II accounting scheme of work comprising of twenty (20) multiple-choice questions were designed by a team of three SS II Accounting teachers. It was constructed based on the Accounting Lesson that was taught. Kolb Learning Style Inventory (LSI) has inbuilt validity and reliability being a universal accepted instrument (Cornwell and Manfredo, 1994). Consequently, both the LSI and the AAT were presented to a team of three experts in Measurement and Evaluation for revalidation of the LSI and full validation of the AAT. The reliability of the instruments (LSI and AAT) were ascertained by the use of Cronbach alpha statistic and Kuder Richardson formula $20(\mathrm{~K}-\mathrm{R}) 20$ respectively. The reliability coefficients for the two instruments were: LSI was gotten at 0.82 while that of AAT was $\mathrm{r}=0.80$.

The data for this study was collected in three phases, which are:

The administration of the Learning style Inventory (LSI)

The administration of the Accounting Achievement Test (AAT) as a pre-test

The administration of the Accounting Achievement Test (AAT) as a post-test

The researcher administered and collected the instruments personally with the help of two well-trained research assistants. Systematically, the procedures that were used in collecting the data for this study are in three phases which are: the pre-treatment phase, the treatment phase and the post-treatment phase. These phases are explained below:

\section{Treatment Procedure}

\section{Pre-Treatment Phase}

The researcher first of all made her intentions known to the Principals and Accounting teachers of the sampled schools. This was to bring about cordial relationship between the researcher and the officials of the schools and discussion on the best way of conducting the research and getting the desired results. Thereafter, the researcher was introduced to the students by the Accounting teachers. Then, the researcher administered the instrument (Kolb Learning Styles Inventory - LSI) to 100 SS II Accounting students for each sampled school. Before administering the inventory, the accounting teachers and the assistants helped the researcher to organize the students in two classes of 50 students each and then the inventory was given to them to fill. The researcher explained the purpose of the inventory to the students as well as the difficult items in the inventory. The purpose of this inventory was to identify the students' learning styles which helped to categorize them according to their learning styles (Accommodating, Diverging, Converging and Assimilating). The determination of the students' learning style preference yielded the baseline data for the study.

The pre-treatment phase also included the administration of the Accounting Achievement Test (AAT) to the students as a pre-test. The purpose of the pre-test was to identify the students' level of performance before the actual lesson was delivered to them (the experimental treatment). The result of the pre-test when compared with that of the post-test helped to determine whether there was improvement after the treatment.

\section{Treatment Phase}

The students were assigned to four experimental and one-control groups respectively based on the result of the inventory. Each experimental group comprised 10 students with the same learning style. These experimental groups were taught using separate teaching $\operatorname{method}(\mathrm{s})$ that match their learning styles. The experiment lasted for five (5) weeks.

Experimental group 1 - E 1 (Accommodators): This group of learners learn by feeling and doing and thus needed visual aids and were provided with charts, models, etc. as curriculum materials. Demonstration, questioning technique and discovery methods are appropriate for this class of learners.

Treatment group 2 - E2 (Divergers): The divergers learn by feeling, watching and observing. They are imaginative-oriented. The above curriculum materials for Accommodators were provided for them. The teaching methods appropriate for them are use of examples, expository and demonstration methods.

Treatment group $3-\mathbf{E}_{3}$ (Convergers): They learn by thinking and doing. They are practical or experimental learners. They learn by doing or experimenting. Curriculum materials were also provided for them and the teaching methods used for them are lecture method with questioning and students' demonstration.

Treatment group 4 - E4 (Assimilators): This group of learners learns by thinking and reasoning. They are rationale or analytic in nature. Curriculum materials were as well provided for them while Questioning techniques, brainstorming and problem solving methods were used to teach them.

The control group: This group was taught with lecture method only and no instructional materials were provided for them. This is to match their performances with those taught with appropriate teaching methods as well as with 
instructional materials and determine if there are differences in their performances.

\section{Post-Treatment Phase}

After the various treatments for each group, the AAT was administered to the students as a post-test, at the same time and under the same conditions.

\section{Method of Data Analysis}

The research questions were answered using mean and standard deviation while the hypotheses were tested using Analysis of Co-Variance (ANCOVA).

\section{Data Analysis}

Research Question 1: What are the learning styles that exist amongst SS 2 Financial accounting students in Owerri Municipal Council?

Table 2: The learning style preference of the accounting students

\begin{tabular}{llrrrr}
\hline Learning Styles & Frequency & Percentage & Mean & \multicolumn{3}{c}{ Std. Deviation Variance } \\
\hline Converger & 101 & $34.8 \%$ & 10.6000 & 4.45278 & 19.8 \\
Assimilator & 86 & $29.7 \%$ & 9.5897 & 3.76761 & 14.195 \\
Diverger & 63 & $21.7 \%$ & 9.3158 & 3.00000 & 9.000 \\
Accommodator & 40 & $13.8 \%$ & 8.0000 & 2.72233 & 7.411 \\
Total & $\mathbf{2 9 0}$ & $\mathbf{1 0 0 \%}$ & & &
\end{tabular}

Table 2 shows that the learning style preference of accounting students is Coverging learning style with a frequency of 101 (34.8\%) followed by Assimilating and Diverging with a frequency of $86(29.7 \%)$ and $63(21.7 \%)$ respectively and finally accommodating learning style with a frequency of 40 (13.8\%).

Table 3: Presentation of adjusted Accounting mean scores of students in each of the learning styles groups and Control group at posttest to determine differences that exist among them.

\begin{tabular}{|c|c|c|c|}
\hline GROUP & $\begin{array}{c}\text { Posttest Adjusted } \\
\text { Accounting mean difference }\end{array}$ & $\begin{array}{c}\text { Adjusted Accounting } \\
\text { mean difference }\end{array}$ & $\begin{array}{c}\text { Average of the adjusted } \\
\text { Accounting mean difference }\end{array}$ \\
\hline Assimilating & 51.94 & \multirow[b]{2}{*}{18.93} & \multirow[b]{2}{*}{42.48} \\
\hline Control & 33.01 & & \\
\hline Accommodating & 42.68 & \multirow[b]{2}{*}{9.67} & \multirow[b]{2}{*}{37.85} \\
\hline Control & 33.01 & & \\
\hline Converging & 59.83 & \multirow[b]{2}{*}{26.74} & \multirow[b]{2}{*}{46.46} \\
\hline Control & 33.01 & & \\
\hline Diverging & 43.23 & \multirow[b]{2}{*}{9.14} & \multirow{2}{*}{38.16} \\
\hline Control & 33.01 & & \\
\hline
\end{tabular}

*The presentation of table 3 serves as a guide in the analysis of the following research questions

Research Question Two: What differences exist in adjusted Accounting mean scores of students in Converging and Assimilating learning styles and Control groups at posttest?

Table 4: Mean analysis of adjusted Accounting mean scores of students in Converging learning style and Control groups at posttest

\begin{tabular}{|c|c|c|c|}
\hline GROUP & $\begin{array}{c}\text { Posttest Adjusted Accounting } \\
\text { mean difference }\end{array}$ & $\begin{array}{c}\text { Adjusted Accounting } \\
\text { mean difference }\end{array}$ & $\begin{array}{c}\text { Average of the adjusted } \\
\text { Accounting mean difference }\end{array}$ \\
\hline Converging & 59.83 & 26.74 & 46.46 \\
\hline Control & 33.01 & 26 & \\
\hline
\end{tabular}

Table 4 shows that the adjusted Accounting mean scores of the Converging and Control groups at posttest are 59.83 and 33.01 respectively. Table 4 also shows that the difference in the adjusted Accounting means is 26.74 and the average of the adjusted Accounting means is 46.46. It can also be observed that whereas the adjusted Accounting mean score for Converging group is above the average of the adjusted Accounting means, the adjusted Accounting mean score for the Control group is below the average of the adjusted Accounting means. It can therefore be inferred that there is a difference in the adjusted Accounting mean scores of the Converging and Control groups at posttest with Converging group achieving better than the Control group.

Table 5: Mean analysis of adjusted Accounting mean scores of students in Assimilating learning style and Control groups at posttest

\begin{tabular}{|c|c|c|c|}
\hline GROUP & $\begin{array}{c}\text { Posttest Adjusted Accounting } \\
\text { mean difference }\end{array}$ & $\begin{array}{c}\text { Adjusted Accounting } \\
\text { mean difference }\end{array}$ & $\begin{array}{c}\text { Average of the adjusted } \\
\text { Accounting mean difference }\end{array}$ \\
\hline Assimilator & 51.94 & 18.93 & 42.48 \\
\hline Control & 33.01 & 183 & \\
\hline
\end{tabular}


Table 5 shows that the adjusted Accounting mean scores of the Assimilator and Control groups at posttest are 51.94 and 33.01 respectively. Table 5 also shows that the difference in the adjusted Accounting means is 18.93 and the average of the adjusted Accounting means is 42.48. It can also be observed that whereas the adjusted Accounting mean score for Assimilating group is above the average of the adjusted Accounting means, the adjusted Accounting mean score for the Control group is below the average of the adjusted Accounting means. It can therefore be inferred that there is a difference in the adjusted Accounting mean scores of the Assimilator and Control groups at posttest with Assimilating group achieving better than the Control group

\section{Analysis and Results with Respect to Hypotheses}

Table 6: Presentation or result of ANCOVA analysis testing for significant differences in the adjusted Accounting mean scores of students in the learning styles groups (Assimilation, Accommodating, Converging and Diverging), Control group and Gender-wise at posttest

\begin{tabular}{|l|c|c|c|c|c|c|}
\hline Source & $\begin{array}{l}\text { Sum Of } \\
\text { Squares }\end{array}$ & Df & Adjusted academic mean Square & F-Computed & F-Critical & Prob \\
\hline Corrected Model & 16976.84 & 10 & 1697.68 & & & \\
\hline Intercept & 19837.61 & 1 & 19837.61 & & & \\
\hline Covariate & 1766.17 & 1 & 1766.17 & & & \\
\hline Group & 11807.80 & 4 & 2951.95 & 37.96 & 2.37 & 0.00 \\
\hline Error & 10810.50 & 139 & 77.77 & & & \\
\hline Total & 552300.00 & 150 & & & & \\
\hline Corrected Total & 27787.33 & 149 & & & & \\
\hline
\end{tabular}

Hypothesis: There is no significant difference in the adjusted Accounting mean scores of students in the Assimilating and Converging learning styles groups and Control group at posttests.

Table 6 shows that the computed-F (37.96) is greater than the critical-F (2.37), and the level of significance $0.05)$ is greater than the Prob (0.00). This result rejects the null hypothesis that there is no significant difference in the adjusted Accounting mean scores of students in the Assimilating and Converging learning styles groups and Control group at posttests., and accepts the alternate hypothesis that there is significant difference in the adjusted Accounting mean scores of students in the Assimilating and Converging learning styles groups and Control group at posttests.

Pair-wise multiple comparisons was generated from Table 6 to find out which of the pair(s) caused the significant difference as expressed by the hypotheses

Table 7: Pair-wise Comparisons of the adjusted Accounting mean scores of students in Assimilating learning style and Control groups at posttest

\begin{tabular}{|l|c|c|c|}
\hline Experimental Group & Adjusted Accounting mean scores & Prob $(\mathrm{p})$. & Significant $(\mathrm{p}<0.05) ?$ \\
\hline $\begin{array}{l}\text { Assimilating } \\
\text { vs }\end{array}$ & 51.94 & 0.000 & Yes \\
Control & 33.01 & & \\
\hline
\end{tabular}

Table 7 shows that for Assimilation and Control, Prob (0.000) is less than the level of significance (0.05). This implies that the adjusted Accounting mean difference of the groups is significant at 0.05 . One can conclude that Assimilating group with higher adjusted Accounting mean score achieves better than the Control group with lower adjusted Accounting mean score.

Table 8: Pair-wise Comparisons of the adjusted Accounting mean scores of students in Converging learning style and Control groups at posttest

\begin{tabular}{|l|c|c|c|}
\hline Experimental Group & Adjusted Accounting mean scores & Prob $(\mathrm{p})$. & Significant $(\mathrm{p}<0.05) ?$ \\
\hline $\begin{array}{l}\text { Converging } \\
\text { vs }\end{array}$ & 59.83 & 0.000 & Yes \\
Control & 33.01 & & \\
\hline
\end{tabular}

Table 8 shows that for Converging and Control, Prob (0.000) is less than the level of significance (0.05). This implies that the adjusted Accounting mean difference of the groups is significant at 0.05 . One can conclude that Converging group with higher adjusted Accounting mean score achieves better than the Control group with lower adjusted Accounting mean score.

\section{Findings}

Generally, the findings suggest that the financial accounting students grouped according to the four learning styles of Kolbs improved in their performances at the post-test. The finding shows that the four learning styles of Kolb were represented amongst the accounting students. The study shows that many students preferred to learn by more than one mode of information presentation. Learning style varies from one group to another based on the nature of the studies, culture or ethnicity, past experience, gender and the characteristics of students. In the study the 
percentage occurrence for converging (28.67), assimilating (26.00), diverging (23.33) and accommodating (22.00). This high percentage for the converging students could be due to the fact that accounting is a subject that involves application in the sense that it uses facts and figures to build ideas, it also involves problem solving, that is, being practical. In accounting, students are meant to do a lot of calculations in form of practical work.

It could also be because accounting students learn by doing and working on problems and cases that allow them to evaluate alternatives and to arrive at answers logically. These findings corroborate with the findings of Novin, Arjomand and Jourdan (2003), who carried out an investigation into the preferred learning styles of accounting, management, marketing, and general business majors. According to their finding, accounting majors most preferred a converger learning style. Convergers are "practical" and need to work through the process of determining how the system works and how it will be useful to them. They are active learners who prefer discovery-type inquiry. Instructional methods that suit convergers include, above all, interactive, not passive style. Computer-assisted instruction is a possibility. Problem sets or workbooks can be provided for students to explore (Litzinger and Osif, 1993, pp. 78- 79). Students who prefer a converger learning style make decisions and solve problems objectively using factual data.

The result obtained from this study showed a difference in the performances of the students with different learning styles at posttest. The study revealed that the mean score of the students with each learning style differed slightly with converging students performing best followed by the assimilators. Statistically, the difference was not significant. The hypothesis that there is no significant difference in the Accounting mean scores of students in the Assimilating and Converging learning styles groups was accepted. There is a positive interaction in the preferred learning styles of the students and their performances. This positive interaction could be as a result of the students' understanding of their various learning style differences. It could also be as a result of a positive interaction among the students or between the students and their teacher in the teaching and learning process. Giving support to this finding, Smith (1974) felt that in order for students to capitalize on their unique skills and abilities, a full understanding of learning style and how it interacts with individual methodologies is paramount.

\section{Conclusion and Recommendations}

This study investigated the Preferred Learning Styles of Accounting Students in Senior Secondary Schools in Imo State, Nigeria. It assess whether accounting students are classified into different learning styles and whether one or more specific learning modes predominate within them. It also looked at how the knowledge and utilization of learners' learning styles in selecting appropriate teaching methods could help to improve performance and also how the possibility of matching appropriate teaching strategies with students learning styles could enhance performance. The cause of poor performance of financial accounting students in both internal and external examinations is of utmost concern to the researcher.

The study will benefit the entire stakeholders to education. This study will create awareness to the students about the different learning styles which will help them discover their own learning styles. To the accounting teachers, it will sensitize them on the problems of individual differences and the students learning styles preference. The Government and the Ministries of Education having knowledge of the findings will be sensitized to recruit only qualified teachers as well as make sure that the teachers are being trained and retrained for understanding better the learning styles impact. To the Curriculum Planners and Experts, the study will guide them to plan the curriculum bearing in mind individual differences in learning styles of students. Two research questions were raised to guide the study, while one hypothesis was formulated to guide this study and was tested at 0.05 level of significance. The quasi-experimental research design was adopted for the study. This type of research deign was used because the researcher did not have full control over some of the intervening variables, that is, those things capable of impinging on the results such as classroom arrangements, health, studying together and or comparing notes, resource available to students beyond treatment session and or after school, etc.

The study was carried in out Imo State but was limited to Public Senior secondary schools in Owerri Municipal Council. The study focused on the students' learning styles and their effects on their performances in Financial Accounting with particular reference to the existence of the four learning styles as identified by Kolb which are Accommodating, Converging, Assimilating and Diverging; and how these affect their performance in financial accounting. The findings shows that the Learning Style Preference of Accounting Students is Converging. Results revealed that when teaching method match the students learning styles they perform better. Based on the findings of the study, the researcher made the following recommendations among others: for better performances in accounting, Accounting teachers should identity the learning styles of their students and use teaching strategies that complements them; varieties in the teaching and learning process like grouping and teaching of students on the basis of their learning style preferences when possible; the Government and the Ministries of Education should recruit only qualified accounting teachers, as well as make sure that the teachers are being trained and retrained through regular organization of seminars and in-service training programmes; adequate relevant instructional materials and facilities should be provided for schools; Curriculum Planners and Experts should plan and organize the curriculum bearing in mind individual differences in learning styles of students, etc. 


\section{References}

Baker, R.E., J. R. Simon, and F.P. Bazeli, (1986). An assessment of the learning style preferences of accounting majors, Issues in Accounting Education Spring, 1-12.

Baldwin, R.A., and PM. Reckers, (1984). Exploring the role of learning style research in accounting education policy, Journal of Accounting Education Fall, 63-76.

Brown, H.D., and R.C. Burke, (1982). Accounting education: A learning-styles study of professional-technical and future adaptation issues, Journal of Accounting Education Fall, 187-206.

Draper, S. R. P. (2004). The Effects of Gender Grouping and Learning Style on Student Curiosity in Modular Technology Education Laboratories. (Doctoral dissertation, the Faculty of the Virginia Polytechnic Institute and State University, 2004), Blacksburg, Virginia. Scholar.lib.vt.edu/../DraperSonya.pdf. Downloaded $7^{\text {th }}$ December, 2021.

Harb, N. and El-Shaarawi, A. (2006). Factors affecting student performance. Munich Personal RePEc Archive Paper No. 13621. Accessed on December 07, 2021 from http://mpra.ub.uni-muenchen.de/13621/.

Honey \& Peter, 2006. Learning Styles Questionnaire, 80 item, July 2006 edition; Maidenhead, UK; ISBN-10: 1902899-6; ISBN-13: 978-1902899-29-9. www.pe-terhoney.com

Kolb, D. A. (1984). Experiential learning: Experience as the source of learning and development. Englewood Cliffs, New Jersey: Prentice Hall. (Retrieved December 07, 2021, from http://www.crit.unmich.edu/occ10.html)

Kolb, D. A. (1999). Learning Style Inventory-version 3: Technical specifications. TRG Hay/McBer, Training Resources Group. 116 Huntington Avenue, Boston, MA 02116,trg_mcber@haygroup.com.

Kolb, D. A. (2000). Facilitator's guide to learning. Boston: McBer.

Litzinger, M. E., \& Osif, B. (1993). Accommodating diverse learning styles: Designing instruction for electronic information sources. In L. Shirato (Ed.), What is good instruction now? Library instruction for the 90 s. Ann Arbor, MI: Pierian Press.

Mbakwem, J. N. and Mkpa, M. A. (2003). Effects of cognitive styles and instructional strategies on students' achievement in Social Studies. Journal of Nigerian Council of Educational Psychologists 1(1), 172 - 193.

McCarthy, M. (2010). Experiential Learning Theory: From Theory to Practice, Journal of Business \& Economics Research 8 (5), 131-139.

Novin, A. M., Arjomand, L. H. and Jourdan, L. (2003). An Investigation into the Preferred Learning Styles of Accounting, Management, Marketing, and General Business Majors. Teaching \& Learning, 18(1), pp. $24-31$.

Salcedo, A. (2021). Preferred learning styles of Accounting Major Students. International Journal of Multidisciplinary: Applied Business and Education Research, 2(7), $549 \quad$ - 556. https://dol.org/10.11594/ijmaber.02.07.02

Smith, R. A. (1974). An exploratory study of cognitive learning style components for achievement using computer simulation games (Doctoral dissertation, Iowa State University, 1974). Dissertation Abstracts International, $35,08 \mathrm{~A}$.

Tanner, K. and Allen, D. (2004). Approaches to biology teaching and learning: learning styles and the problem of instructional selection- engaging all students in science courses. Cell Biol Educ 3: 197-201.

\section{Biographies}

First Author: Dr. Nkeiruka Princess Francis is Lecturer at Imo State University, Owerri, Imo State, Nigeria. She holds NCE in Business Studies from Alvan Ikoku Federal College of Education, Owerri, Bachelor's Degree in Education Accountancy, Masters and Doctorate Degrees in Curriculum Studies from the Imo State University, Owerri. She is an erudite scholar, seasoned academician and a prolific writer. Her teaching prowess spans through all levels of academic endeavours ranging from primary level to university level. She is a wonderful teacher because of her vast exposure. Dr. Nkeiruka Francis has been published by several journal organizations both locally and internally. She is a member of several academic organizations including Curriculum Organization of Nigeria (CON), World Council of Curriculum and Instruction (WCCI), etc.

Second Author: Oruwari Joy Ngozi is a Senior Lecturer at the Alvan Ikoku Federal College of Education, Owerri, Imo State, Nigeria. She holds Bachelor's Degree in English Language Education from the University of Nigeria, Nsukka, Masters and Doctorate Degrees in Curriculum Studies from the Imo State University, Owerri. She is a member of several academic organizations including Curriculum Organization of Nigeria (CON). Her primary research interests are in teacher education and gender where she has authored a number of articles and books. 